\title{
Medieval élite burials in eastern Mecklenburg and Pomerania
}

\author{
Felix Biermann*
}

High status burial remains one of archaeology's most evocative types of site - but it is not always easy to know why they were built, where and when they were. The author describes a group of élite burials that appeared in north Europe in the late eleventh-twelfth century in a historical context that is unusually clear, and proposes the rise of a pagan élite in the face of aggressive Christianisation from the neighbours.

Keywords: medieval, Pomerania, Mecklenburg, Baltic, élite burials, barrows, Christianisation

\section{Introduction}

Eastern Mecklenburg and Pomerania on the south side of the Baltic Sea (Figure 1) were settled by the Slavic tribes of the Pomeranians, Rugians (Rani) and Luticians during the early medieval period. During the late eleventh and twelfth centuries these territories came under intense pressure. The foundation of central powers caused inner struggles, first of all in the Pomeranian duchy of the Greif family which expanded between AD 1125 and 1128 into the Lutician regions west of the river Oder. At the same time the territory was the target of military aggression by powerful neighbours: the German Empire, the Polish Piasts and the Danish Kingdom. Pomeranians, Rani and Luticians had resisted Christianisation up to the twelfth century, but now missionary activities started with the word and the sword. Well-known events are Bishop Otto of Bamberg's two mission journeys to Pomerania in 1124/1125 and 1128, the Wends Crusade by North German magnates in 1147 and the Danish attacks of the 1160s. The destruction of the famous Rugian Svantevit temple at Arkona in 1168 can be understood as a symbol for the end of paganism in the territories of the southern Baltic Sea coast.

In eastern Mecklenburg and Pomerania the cremation burial custom dominated at least up to the late tenth century (Zoll-Adamikowa 1994: 82). But in the eleventh and twelfth centuries, a group of inhumation burials of very high status briefly appeared (Figure 1). The new burials are characterised by exceptional grave goods, including swords, spurs, bronze bowls and lavish burial structures. Some of them can be described as élite graves, because they reflect a significantly higher level of burial status and contain prestigious, sometimes imported, objects. Their character indicates extraordinary funeral rites (for a definition see Kossack 1974: 4-5; Eisenschmidt 1994: 24; Steuer 2006). The common Slavic burial of that time was a simple inhumation grave with a few items only, such as knives and single pieces

* Prehistoric Branch, Humboldt University Berlin, Hausvogteiplatz 5-7, 10117 Berlin, Germany (Email:biermanf@geschichte.hu-berlin.de) 


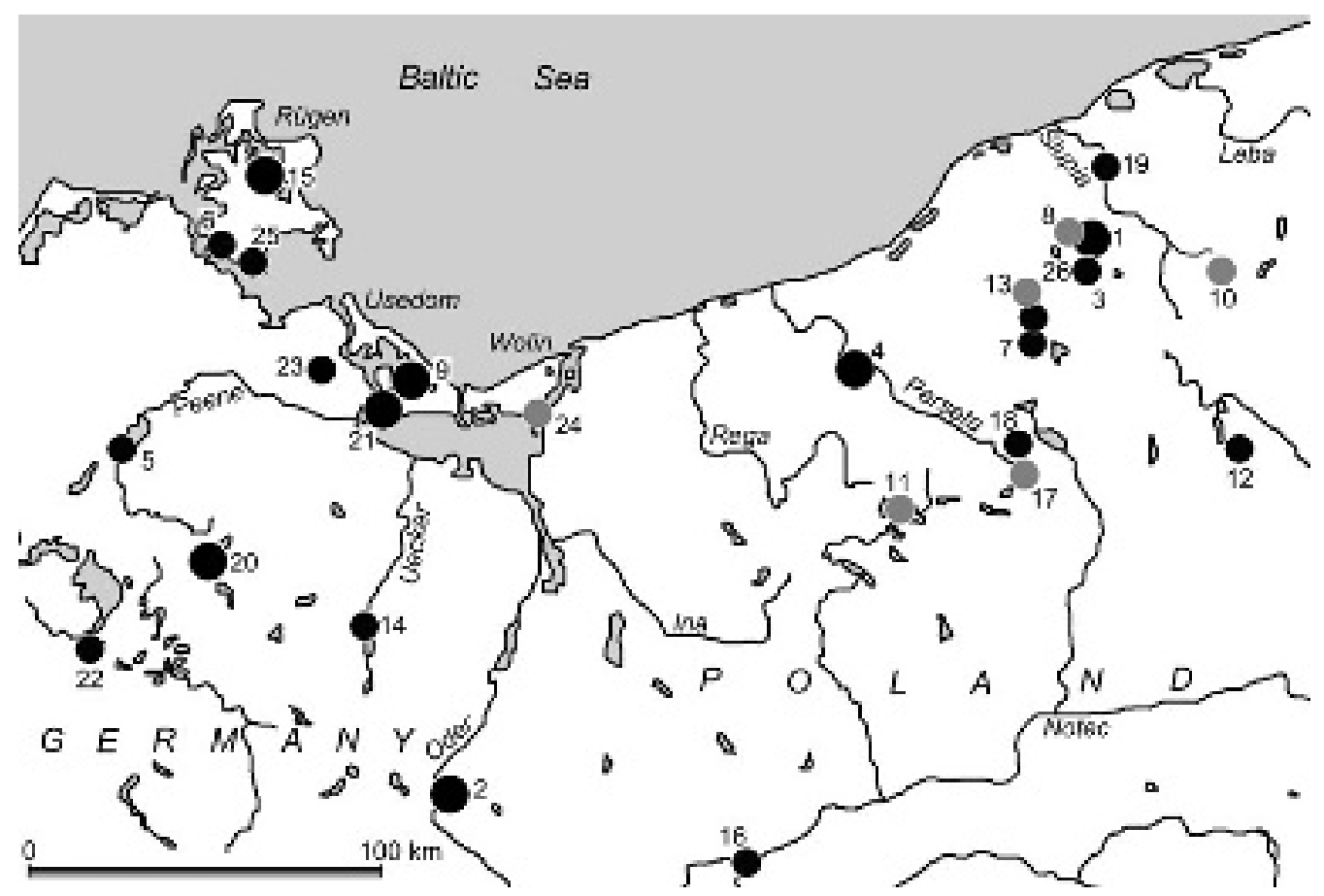

Figure 1. Map of eastern Mecklenburg and Pomerania with the outstanding graves discussed in the text. Black spots: élite burials; black dots: poorly documented weapon graves or graves with swords only; grey dots: graves with bronze bowls. 1 Barwino; 2 Cedynia; 3 Ctecholub; 4 Dębczyno; 5 Gorschendorf; 6 Gustow; 7 Kęsko; 8 Korzybie; 9 Neppermin; 10 Niezabyszewo; 11 Piaseczno; 12 Pawłowko; 13 Polanów; 14 Prenzlau; 15 Ralswiek; 16 Santok; 17 Sitno; 18 Skotniki; 19 Stupsk; 20 Usadel; 21 Usedom; 22 Vipperow; 23 Wahlendow; 24 Wolin; 25 Zudar; 26 Zydowo (drawing F. Biermann).

of jewellery. Many questions are connected with these élite graves, concerning their social and political meaning, their traditions and possible influences and the role of Scandinavian contacts.

The goal of this paper is to discuss the context and the interpretation of this group of élite burials, comparing the archaeological and historical evidence. First, one of the most impressive tombs of this type, the recently excavated chamber grave of Usedom will be presented, followed by a brief overview of other burials of the type in eastern Mecklenburg, in Pomerania and in more distant areas. Finally, the article will discuss traditions, foreign influences, social and ethnic conditions relevant for the interpretation of the graves.

\section{The example of Usedom}

In the year 2000 Holger Fries excavated one of the most magnificent graves of medieval Pomerania in the town of Usedom (district of Ostvorpommern) on the island of the same name in the Oder estuary (Figure 1, no. 21). The castle-town of Usedom was an economically and politically important harbour and market complex in the eleventh and twelfth centuries. In its initial phase Usedom was probably a capital of a Lutician dominion, and after the Pomeranian conquest, shortly before 1128, it developed into one of the most significant residences of the Greif Dukes (Biermann 2006). 
In the neighbourhood of the main stronghold of Usedom a large cemetery of the late tenth to twelfth century was situated in a place named 'am Hain'. There, about 200 graves have been discovered - in most cases poorly furnished inhumation burials. At the periphery of the site, a single grave (no. 135; Figures 2 and 3) was found with traces of a rectangular

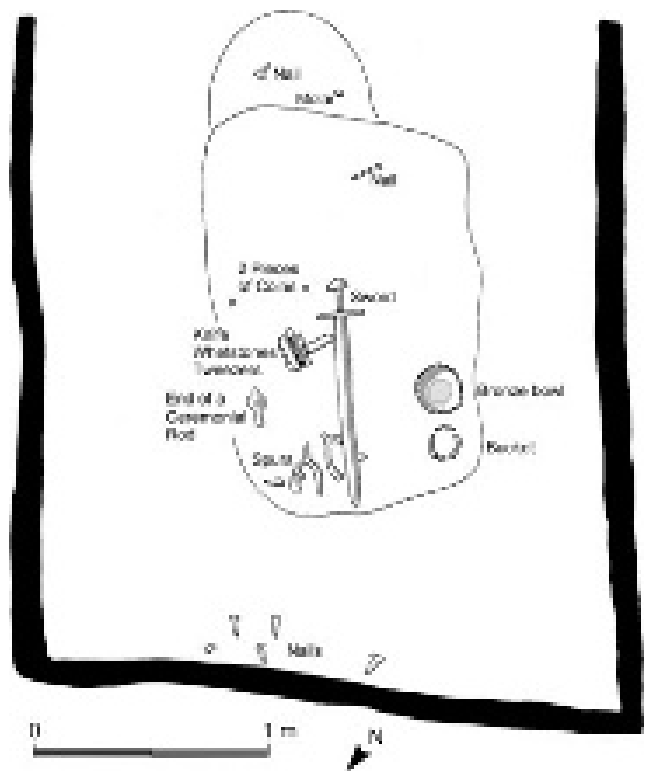

Figure 2. Usedom: plan of chamber grave (no. 135) (drawing F. Biermann). wooden chamber measuring $3.1 \times 2.7 \mathrm{~m}$ with a depth of $c .0 .2 \mathrm{~m}$. The limited depth of the chamber is a result of later erosion and long-term agriculture; it also suggests that the grave was originally covered by an earth mound. The chamber was probably of plank construction (Eisenschmidt 1994: 29). Some nails were found which were concentrated in the northern part of the chamber (illustrated in Figure 3. nos. 1214). It is possible that they indicate a boat plank used as part of the construction, as in other graves of this cemetery (Biermann 2004). In the chamber a corpse was lying approximately north-south with the head towards the south. Unfortunately the body had decayed to near invisibility and only some stains and one molar were seen.

The grave goods were much better preserved. A sword was placed near the legs of the dead person (Figure 3.6), its blade ornamented with two inlaid silver rosettes. The plain grip ends in a massive pommel. Traces of a wooden sheath could also be observed. The weapon is a late variant of type Petersen $\mathrm{X}$, which was common in the Baltic mainly in the eleventh-twelfth centuries; the shape of the pommel and the geometric blade decoration support this dating (Geibig 1991: 112-4, 156; Nadolski 1954: 245-6; Schmidt 1992: 48). A pair of iron spurs decorated with silver (Figure $3.10,11$ ) featured a type of stimulus without parallel, but according to the general type (form D II, Goßler 1998) and particularly because of the double eyelets the object can be dated to the eleventh-twelfth centuries. Sword and spurs can be interpreted as status symbols during the Scandinavian Viking age as well as in the Slavic territory.

On the left side of the dead person's foot there were placed an ornamental bronze washing bowl and a bucket (Figure 3.1, 7), important status symbols serving refined upper class customs. The bronze bowl is engraved with geometrical ornament and belongs to type $\mathrm{Vb}$ of T. Poklewski (1961: 25) or type E of U. Müller (1998: 318-21; 2006: 135-9), both dated mainly to the late eleventh and twelfth centuries. The grave also contained two whetstones probably from Scandinavia (Figure 3.4, 5), an iron knife with sheath (Figure 3.8), a pair of bronze tweezers (Figure 3.2), some ceramic fragments (Figure 3.3) and the end of a rod consisting of an iron ring and a pin (Figure 3.9). This was part of a ceremonial rod with parallels in Mecklenburg and Pomerania (Schmidt 1992: 28-30). Two silver coins are of special importance. One was identified as a Sachsenpfennig from the Meißen-Lusatian region, struck 

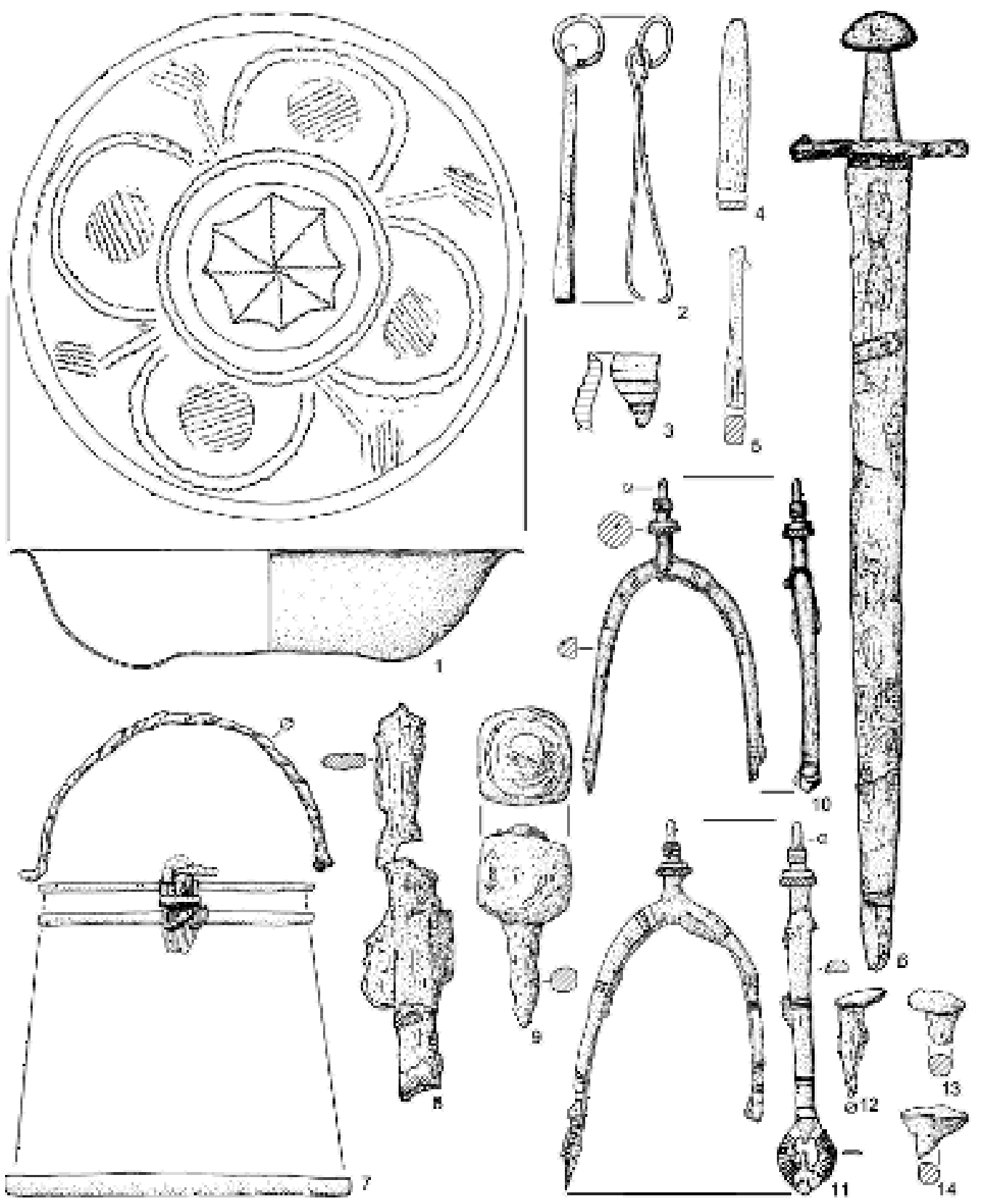

Figure 3. Usedom: equipment from the chamber grave. 1 bronze bowl; 2 bronze tweezers; 3 ceramic fragment; 4, 5 whetstones, slate; 6 iron sword; 7 iron and wooden remains of the bucket; 8 iron knife, sheath with bronze fittings; 9 iron end of a ceremonial rod; 10, 11 iron spurs; 12-14 iron nails. 1-5, 7-14 Scale 1:3; 6 original length 98cm (drawing F. Biermann, C. Köhler)

between AD 1030 and 1060 (determination: Wolfgang Virk). The bad state of preservation suggests prolonged use of the coin. It provides a terminus post quem, after 1030, for the burial. 


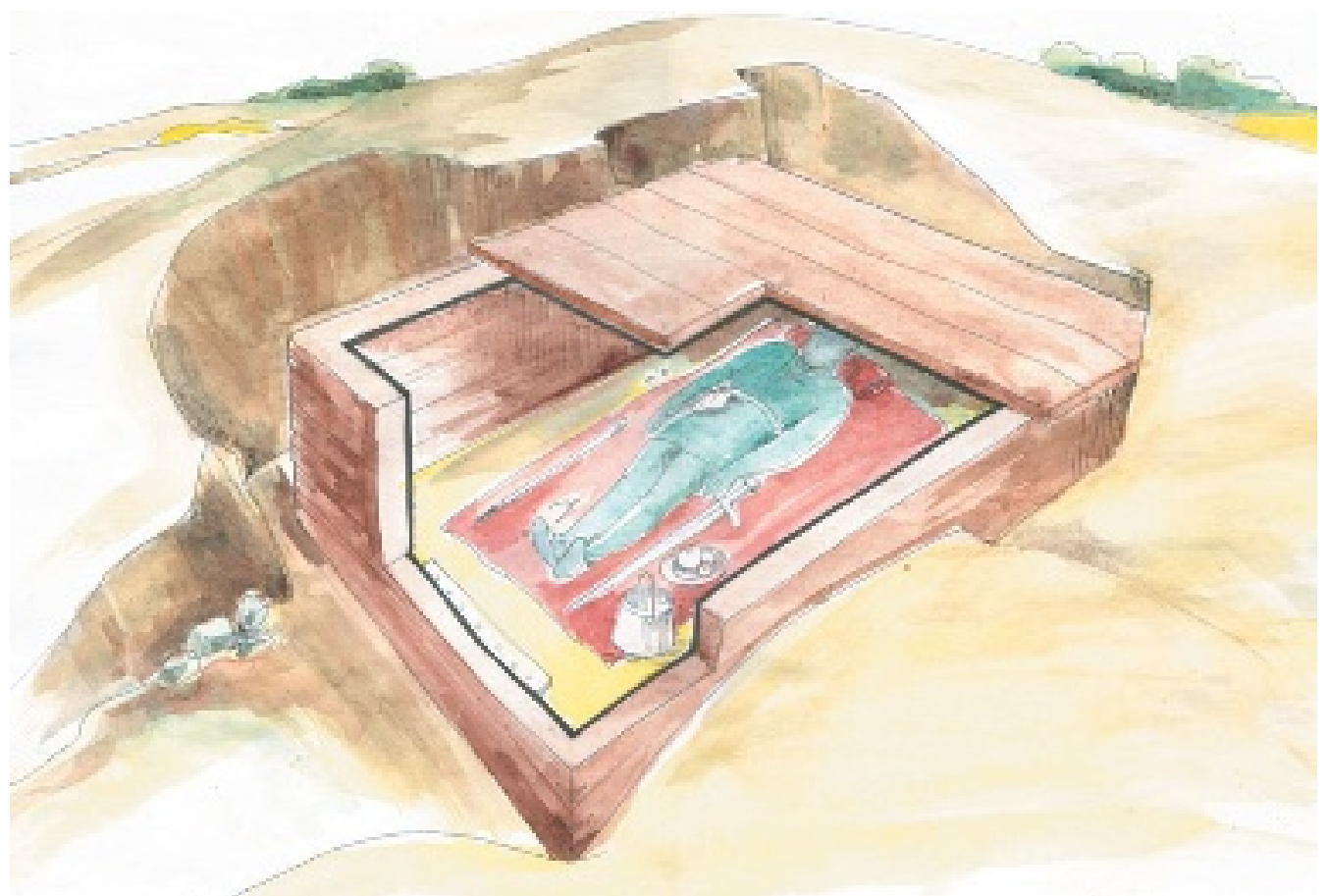

Figure 4. Usedom: reconstruction of the chamber grave (drawing S. Fiedler).

The burial (reconstructed in Figure 4) can be dated most probably to the late eleventh or first third of the twelfth century (revising a former dating to the late tenth century: Fries 2001: 301). Following Anne Pedersen (2002: 85-7), the burial can be classified as a warrioror rider-grave. The buried man might have been a chief of the Luticians. It is possible following the ideas of O. Kossmann (1971: 677-8) concerning Usedom - that the grave represents the 'Oder Prince' Zuetopolk of the Selencia district, who was killed in 1122 according to a Polish chronicle. However, the person might also represent a high ranking warrior from the retinue of the Pomeranian Dukes who ruled Usedom after $c .1128$.

\section{Other chamber graves in eastern Mecklenburg and Pomerania}

This grave can be seen as one of a group of similar type and date (for distribution see Figure 1). Two chamber graves from the Usadel cemetery near Neubrandenburg (Figure 1, no. 20) provide important parallels for Usedom. The cemetery, with a total of 129 graves, belonged to the settlement complex of Lieps, identifiable perhaps with the famous Rethra. Burial no. 38 was a chamber grave measuring $3.4 \times 2.0 \mathrm{~m}$ and more than $1 \mathrm{~m}$ deep, encircled by a wooden post construction. The buried person was equipped with a sword (Petersen type $\mathrm{X}$ ), a fire-steel and a clasp-knife. The sword dates the grave to the eleventh or twelfth century. The second grave, no. 100, was a large rectangular building in log construction on a stone base, measuring $2.5 \times 1.0 \mathrm{~m}$ and $1.5 \mathrm{~m}$ deep. The grave contained a skeleton accompanied by a single-blade sword, a knife, the grip of a riding whip, two silver-inlaid spurs, ceramics, and a coin (c. 1080-1150). The pit of grave 100 gave a dendrochronological date from charcoal 


\section{Felix Biermann}
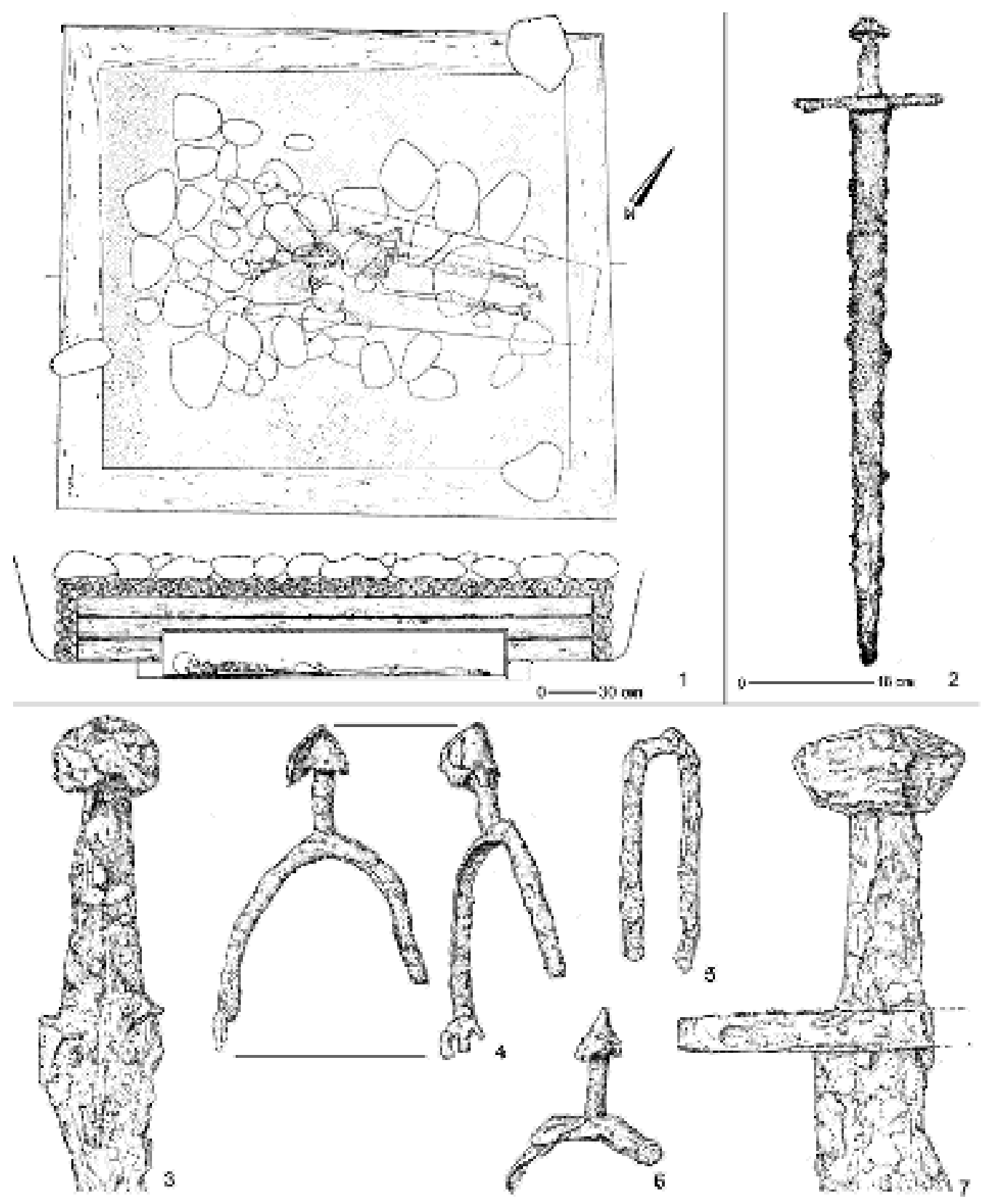

Figure 5. Cedynia: chamber grave 558. Plan, reconstruction and sword (1-2). Neppermin: grave goods; swords, spurs, firesteel (3-7). (After Malinowska-Lazarczyk 1982: Figure 10; Eggers 1985: plates 68, 69).

to 'around/after 1150' (last tree-ring: 1137; Schmidt 1992: 90-1). The building erected above grave 100 was interpreted as a 'dead man's house', although recently re-interpreted as remains of a wooden church (Pollex 2007: 372).

Among many hundreds of graves from the tenth-fourteenth centuries in the cemetery at Cedynia south of Szczecin (Figure 1, no. 2) one chamber grave (no. 558) was defined 
(Figure 5). The chamber was rectangular and log-built, measuring $2.3 \times 2.8 \mathrm{~m}$ and 0.8 $1.2 \mathrm{~m}$ deep. The structure was covered by large stones and probably also by a mound. Inside the chamber there was a coffin containing a west-east-oriented skeleton with a sword (Type Petersen X or Nadolski $\alpha$ ), a knife and a bronze strap-end. The sword dates it to the twelfth century. A second outstanding grave (no. 1120), an inhumation in a coffin, contained a sword of late Petersen X type, a spur and a knife. It is also dated to the late eleventh-twelfth centuries (Malinowska-Łazarczyk 1982; 1985).

The group contains a number of other élite burials, although their documentation is often incomplete, particularly concerning their grave layout, since they were mostly excavated before the Second World War (for the find spots see Figure 1; and see Table 1 for the grave goods). For example, in Neppermin, rich weapon graves from the twelfth century were found (Figure 5.3-7; Corpus 2, 1979: 44, 99); in Barwino, near Miastko, three graves were found by accident in 1924 and 1937 (Figure 6). The first grave contained a sword (Petersen X), a

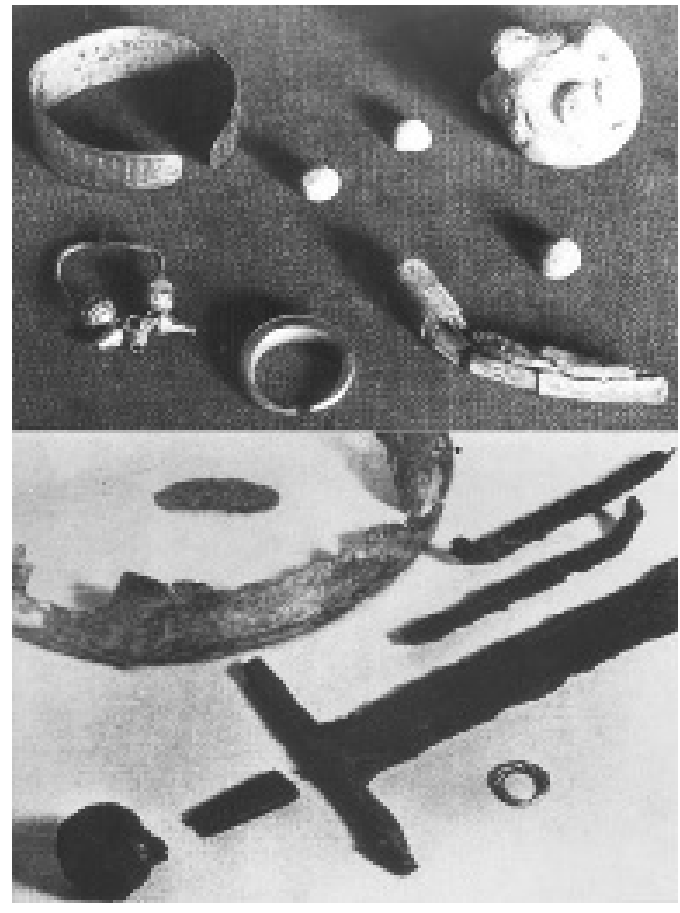

Figure 6. Barwino: finds from the graves. Below: bronze bowl, sword, fragments of a stirrup (?) and silver ring from grave 1. Above: a clay rattle, three rings and a beaver tooth amulet from grave 3 (pre-WWII photographs, after Beck 1945: Figure 61). bronze bowl, two silver finger rings and a stirrup (?), the second grave a silver ring and an axe. The third grave was a female burial equipped with whetstones, a clay rattle, a bucket, a temple ring, a beaver tooth amulet and further goods. Again the outstanding quality supports the interpretation as an élite graveyard. Most probably it can be dated to the late eleventh or twelfth century (Beck 1945, Kat.-Nr. 3; Eggers 1978: 185).

In summary, the élite graves of eastern Mecklenburg and Pomerania feature rich grave goods, sometimes stone cairns, a chamber construction, and a grave mound or buildings above the surface and can be characterised by one or more of these attributes. Some of the graves are found in separated graveyards probably of the aristocracy and their entourage. Other examples are found within larger cemeteries. The Usadel chamber grave 100 is (exceptionally) dated to the mid twelfth century by dendrochronology. Other élite burials can be generally assigned to the eleventh or in most cases - to the twelfth century. No grave seems to date from the tenth century.

\section{Discussion}

We can find the first parallels to the southern Baltic chamber graves in Scandinavia at an earlier date. Ostentatious chamber graves are well-known there, especially from Denmark 
Table 1. Selected equipment and burial lay-out of sword graves in eastern Mecklenburg and Pomerania (Ced.: Cedynia; Nepp.: Neppermin; Gor.: Gorschendorf). Dark grey: existing item; light grey: uncertain signs of a chamber; white: no existing item.

\begin{tabular}{|c|c|c|c|c|c|c|c|c|c|c|}
\hline & Suced & Chanber & $\begin{array}{l}\text { Riding } \\
\text { equit. }\end{array}$ & Knift & $\begin{array}{l}\text { Prenose } \\
\text { Lowm }\end{array}$ & Buxist & Cein & $\begin{array}{l}\text { Firget- } \\
\text { fins }\end{array}$ & $\begin{array}{l}\text { Fit:- } \\
\text { fosel }\end{array}$ & $\begin{array}{l}\text { Culer } \\
\text { itturs }\end{array}$ \\
\hline \multicolumn{11}{|l|}{ Unbing } \\
\hline \multicolumn{11}{|l|}{ UnEe: 39} \\
\hline \multicolumn{11}{|l|}{ Unas' 160} \\
\hline \multicolumn{11}{|l|}{$\operatorname{CoL} .555$} \\
\hline \multicolumn{11}{|l|}{$\operatorname{Cos} 1120$} \\
\hline \multicolumn{11}{|l|}{ Nepe. 5} \\
\hline N=다. 6 & & $?$ & & & & & & & & \\
\hline \multicolumn{11}{|l|}{ Baruins ] } \\
\hline \multicolumn{11}{|l|}{ Choiknala } \\
\hline \multicolumn{11}{|l|}{ Gistum 1} \\
\hline \multicolumn{11}{|l|}{ Guslum II } \\
\hline \multicolumn{11}{|l|}{ Vippems } \\
\hline Whàltndun & & $?$ & & & & & & & & \\
\hline Paulinkit & & $?$ & 7 & $?$ & & $?$ & $?$ & ? & 2 & $\%$ \\
\hline Prumblau & & $?$ & 7 & $?$ & $?$ & $?$ & $?$ & $?$ & $?$ & $?$ \\
\hline Gis. & & $?$ & $?$ & $?$ & $?$ & $?$ & $?$ & ? & $?$ & ? \\
\hline 7nder & & $?$ & 7 & $?$ & $?$ & $?$ & $?$ & 3 & $?$ & $?$ \\
\hline Slapk & & $?$ & $?$ & 9 & $?$ & $\bar{\gamma}$ & $?$ & $?$ & $?$ & 9 \\
\hline $7 y$ dinms & & $?$ & 7 & ? & $?$ & ? & $?$ & ? & $?$ & $?$ \\
\hline
\end{tabular}

and Scania, but also from central Sweden. The use of the burial rite in Scandinavia increased from the ninth century onwards, perhaps under continental influence, flourished in the tenth century and came to an end around AD 1000. Scandinavian chamber graves were in most cases constructed with a wooden chamber and were sometimes log-built and often covered with a mound. Stone layers are also reported. They usually contain an inhumation burial oriented west-east, but particularly in Scania and Bornholm a north-south-orientation is also common. The grave equipment is usually characterised by swords, riding equipment, bronze bowls, buckets and personal items (Gräslund 1981: 27-43, 45-6; Eisenschmidt 1994). In many respects the Scandinavian tombs are similar to the Pomeranian and Mecklenburgian 
burials, but predate them; when the custom started in the south, the burial custom had already been obsolete for decades in Scandinavia.

Scandinavian influence has often been proposed, particularly for the graves with bronze bowls (Beck 1945; Müller 1998: 314-6; Janowski \& Kurasinski 2003), which find contemporary analogies in burials on the island of Gotland (Trotzig 1991). Naturally it has even been suggested that Scandinavians were buried in the Pomeranian and Mecklenburgian chamber graves (Fries 2001: 300-1), an interpretation also suggested for the élite graves in the Wisła region (Kara 1998; Chudziak 2004). Indeed, the parallels between Scandinavian and Slavic burials north and south of the Baltic, in the cases of chamber graves such as Usedom, Usadel and Cedynia, are remarkable.

It is improbable that the southern Baltic élite burials from the later eleventh and twelfth centuries emerged from local tradition because precursors are missing in our territory in the tenth and early eleventh centuries. But a direct transfer of the practice from Denmark to Pomerania seems improbable since there is no continuity in the dating. A link between the Scandinavian graves and the ones discussed here might be found in the rich weapon burials from the period around AD 1000 and the eleventh century in Greater Poland and Kujawia. They are equipped with battle-axes, spearheads or swords of Nordic origin, riding equipment, sometimes buckets and other items, and occasionally they have chambers or stone layers. Examples of such graves are Lutomiersk (Brather 2001: 56), Poznań-Lubon, Lubówko and Skokówko (Kara 1992: 167-74). The rich graveyard from Sowinki, near Poznań, featured several lavish graves with weapons and a richly furnished chamber grave, dated to the last quarter of the tenth century by a coin and other finds (Krzyszowski 1997: 639, 663-4).

These Polish graves have been interpreted, particularly by Michał Kara (1992: 167-74), as those of hired Scandinavians, especially central Swedish or Varangian warriors, serving in a retinue of the early Piasts, and without doubt the weapons and perhaps also the burial custom were of Scandinavian origin (Kara 1992: 168). However, this interpretation is not absolutely convincing. There are other ways of explaining northern references in the tombs of the armed élite of the Piast power than ethnic origin (Brather 2001: 57-8). But these Polish graves might have influenced Pomerania and eastern Mecklenburg. In spite of the military unrest, there were intensive cultural relations between Luticians, Pomeranians and Poles, and we can propose a strong fascination among the Luticians and Pomeranians with the culture of the Polish élite.

An alternative interpretation for the Pomeranian and eastern Mecklenburgian graves might be influence from Scandinavia by oral history. The splendour and greatness of the earlier times might have been alive in the mythological tales of the new upper class. The heyday of the old Vikings could have provided a powerful example for the Slavic rulers on the Baltic coasts in the eleventh-twelfth centuries. It is possible that in this context memories of the old ostentatious burial customs were part of the traditions because they had a considerable importance for the Viking élite.

In general, chamber graves can have a social, religious and ethnic meaning (Steuer 1984: 339-66; 2006). If we follow the arguments outlined above, we can discount the latter interpretation here: there are no indications that outsiders were buried in the Pomeranian élite graves, only members of the local Slavic leading group. In the light of the rich equipment 
and the lavish burial structure, the high rank of the buried persons is indisputable. The élite based its identification on military power, reflected by the weapon-equipped burials. Swords were the dominant status symbol, and riding equipment was an additional sign of prestige. The high status and a developed lifestyle are also illustrated by hand washing bowls, buckets and tweezers. Although rarer, rich female graves exist, suggesting that both sexes were part of the élite (e.g. Dębczyno; Kóčka-Krenz \& Sikorski 1998). The leading group celebrated itself in splendid funeral events and magnificent burials. They were prepared for a warlike and luxurious hereafter, but in this world demonstrated their social status as members of a self-confident group. In this sense, the funeral rites were a method of communication between the élite and their communities (Pedersen 1997: 269-71). At the same time, the rich graves show a strong social hierarchy in Slavic society, particularly reflected by the separated graveyards. These and the high status burial groups at larger cemeteries show that the élite consisted not only of single persons but of families.

Seeking alternative interpretations, we can note that the élite graves of eastern Mecklenburg and Pomerania were created at the time of Christianisation, at a time of struggles for power and the growth to power of the Pomeranian duchy. Taking into account the amount of grave goods and the chambers, which perhaps served as 'houses of the dead', the burials seem to be pagan. However, Christian customs and rich grave equipment were probably not an absolute contradiction in this region at that time. This was especially the case when the representative function of the equipment was more focused on this world than on the hereafter. In the tenth century, when analogous funeral customs flourished in Denmark, such burials were absent in Pomerania and eastern Mecklenburg. But the arrival of chamber graves on the southern Baltic coast some decades later may perhaps be explained in a similar way: the Danish magnificent burials of the tenth century - just like other such burials interpreted in different contexts (Kossack 1974: 28-33; Carver 1998: 266-7) - are often interpreted as a reaction by the indigenous nobility to a crisis; in this case Christianisation might have been perceived as a threat from the outside. Using lavish burials, the élite could demonstrate their power, the high reputation of their families and their pagan traditions to their own subjects and to foreigners. These graves reflect a combination of elements of the peoples' own heritage and foreign influences (Eisenschmidt 1994: 74, 81; Pedersen 1997: 271; 2002: 91-2; Roesdahl 2006: 174). 'The need to be laid to rest in a lavish way always arose in an upper class when pressure was put on it by another, superior society' (Eisenschmidt 1994: 74; own translation).

\section{Conclusion}

This interpretation might also fit the late Slavic élite burials: in the eleventh-twelfth centuries, Pomerania and Mecklenburg were the target of Christianisation and military aggression by the Danes, Germans and Poles, and the aristocracy had to struggle for power in their lands. In these troubled times, leaders wanted to demonstrate their power, high standing and independence by élite graves, based on their own funeral traditions but emulating earlier Scandinavian or Polish models. In this respect the élite burials discussed here are not only monuments of pronounced social differentiation and a warrior society but also witnesses of a period of radical change in Slavic society in the southern Baltic area. 


\section{Medieval élite burials in eastern Mecklenburg and Pomerania}

\section{References}

Beck, A. 1945. Die slavischen Grabfunde Pommerns. Unpublished Dissertation, Greifswald University (summary in Baltische Studien, Neue Folge 55, 1969: 7-32).

Biermann, F. 2004. Usedomer Bootsgräber. Germania 82: $159-76$.

-2006. Usedom - an early and high medieval political and economic centre in the Oder estuary, in K. Møller Hansen \& K. Buck Pedersen (ed.) Across the western Baltic: 293-303. Vordingborg: Sydsjaelands Museum.

Brather, S. 2001. Lutomiersk, in Reallexikon der Germanischen Altertumskunde 19: 56-8. Berlin \& New York: Walter de Gruyter.

Carver, M. 1998. Überlegungen zur Bedeutung angelsächsischer Grabhügel, in A. Wesse (ed.) Studien zur Archäologie des Ostseeraumes von der Eisenzeit bis zum Mittelalter. Festschrift für Michael Müller-Wille: 259-68. Neumünster: Wachholtz.

Chudziak, W. 2004. Niektóre okoliczności przepływa rzeczy i idei we wczesnym średniowieczu instruktywne przyklady "chełmińskie", in S. Możdzioch (ed.) Wędrówki rzeczy i idei w średniowieczu: 183-97. Wrocław: Polska Akademia Nauk.

Corpus, edited by J. Herrmann \& P. Donat. Corpus archäologischer Quellen zur Frühgeschichte auf dem Gebiet der Deutschen Demokratischen Republik (7. bis 12. Jahrhundert),Volume 1, 1973; Volumes 2 \& 3, 1979. Berlin: Akademie der Wissenschaften.

Eggers, H. J. 1978/1985. Funde der wendisch-wikingischen Zeit in Pommern (Text \& Tafeln). Kiel: Stiftung Pommern.

EISEnschmidt, S. 1994. Kammergräber der Wikingerzeit in Altdänemark. Bonn: Habelt.

Fries, H. 2001. Das Kammergrab von Usedom, Lkr. Ostvorpommern. Ein Vorbericht.

Bodendenkmalpflege in Mecklenburg-Vorpommern, Jahrbuch 2000: 295-302.

GeIBIG, A. 1991. Beiträge zur morphologischen Entwicklung des Schwertes im Mittelalter. Neumünster: Wachholtz.

GoßLER, N. 1998. Untersuchungen zur Formenkunde und Chronologie mittelalterlicher Stachelsporen in Deutschland (10.-14. Jahrhundert). Berichte der Römisch-Germanischen Kommission 79: 479663.

Gräslund, A.-S. 1981. Birka IV. The Burial Customs: a study of the graves on Björkö. Stockholm: Royal Academy of History, Antiquity and Letters.

Janowski, A. \& T. Kurasinski. 2003. The graves with bronze bowls in the area of Early-Piast Poland $\left(10^{\text {th }} / 11^{\text {th }}\right.$ to $12^{\text {th }}$ century). Issues of

Slavic-Scandinavian contacts. Archaeologia historica 28: 653-75.
Kara, M. 1992. The graves of the armed Scandinavians from the middle and the younger Viking period from the territory of the first Piasts' state, in 'Death and burial', pre-printed papers 4, Medieval Europe 1992: a conference on medieval archaeology in Europe, 21-24 September 1992 at the University of York: 167-76. York: Medieval Europe.

-1998. Wczesnośredniowieczny grób uzbrojonego kupca z miejscowości Ciepłe na Pomorzu Gdańskim w świetle ponownej analizy chronologicznej, in: H. Kóčka-Krenz \& W. Łosiński (ed.) Kraje stowiańskie w wiekach średnich. Profanum i Sacrum: 505-524. Poznań: Wydawnictwo PTPN.

KóčKa-KREnz, H. \& A. SiKorsKi. 1998. Grób, książniczki’ z Dębczyna koło Białogardu w woj. koszalińskim (stan. 53), in H. Kóčka-Krenz \& W. Łosiński (ed.) Kraje stowiańskie w wiekach średnich. Profanum i Sacrum: 525-35. Poznań: Wydawnictwo PTPN.

Kossack, G. 1974. Prunkgräber. Bemerkungen zu Eigenschaften und Aussagewert, in G. Kossack \& G. Ulbert (ed.) Studien zur vor-und frühgeschichtlichen Archäologie I: 3-33. München: Beck.

Kossmann, O. 1971. Das unbekannte Land Selencia und die Anfänge Pommerns. Zeitschrift für Ostforschung 20: 641-85.

Kryszowski, A. 1997. Frühmittelalterliches Grab eines Kaufmannes aus Sowinki bei Poznań in Großpolen. Germania 75: 639-71.

MalinowsKa-ŁazarCzyK, H. 1982. Cmentarzysko średniowieczne $w$ Cedyni I-II. Szczecin: Muzeum Narodowe.

-1985. Badania wykopaliskowe na cmentarzysku w Cedini w latach 1976-1985. Materiaty Zachodniopomorskie 31: 85-115.

MüLLER, U. 1998. Gravierte Bronzeschalen im nördlichen Ostmitteleuropa, in C. Lübke (ed.) Struktur und Wandel im Früh-und Hochmittelalter: 313-32. Stuttgart: Franz Steiner.

-2006. Zwischen Gebrauch und Bedeutung. Studien zur Funktion von Sachkultur am Beispiel mittelalterlichen Handwaschgeschirrs (5./6. bis 15./16. Jahrhundert). Bonn: Habelt.

NADOLSKI, A. 1954. Studia nad uzbrojeniem polskim w X, XI a XII wieku. Łódż: Zakład im. Ossolińskich.

Pedersen, A. 1997. Søllested and Møllemosegård. Burial Customs in $10^{\text {th }}$-century Denmark, in M. Müller-Wille (ed.) Rom und Byzanz im Norden I: 249-78. Stuttgart: Franz Steiner.

-2002. Prachtgräber des 10. Jahrhunderts in Südskandinavien - Tradition und Erneuerung, in J. Henning (ed.) Europa im 10. Jahrhundert: 81-94. Mainz: von Zabern. 


\section{Felix Biermann}

Poklewski, T. 1961. Misy brazowe z XI, XII i XIII wieku. Łódż: Zakład narodowy im. Ossolińskich.

Pollex, A. 2007. Der Übergang zur Körperbestattung bei den Nordwestslawen II, in F. Biermann \& Th. Kersting (ed.) Siedlung, Kommunikation und Wirtschaft im westslawischen Siedlungsraum: 363-92. Weissbach: Beier \& Beran.

Roesdahl, E. 2006. Aristocratic burial in late Viking age Denmark, in C. von Carnap-Bornheim et al. (ed.) Herrschaft - Tod Bestattung (Kongress Kiel 2003): 169-83. Bonn: Habelt.

Schмidt, V. 1992. Lieps. Die slawischen Gräberfelder und Kultbauten am Südende des Tollensees. Lübstorf: Archäologisches Landesmuseum Mecklenburg-Vorpommern.
Steuer, H. 1984. Soziale Gliederung der Bevölkerung von Haithabu nach archäologischen Quellen, in H. Jankuhn, K. Schietzel \& H. Reichstein (ed.) Archäologische und naturwissenschaftliche Untersuchungen an ländlichen und frühstädtischen Siedlungen im deutschen Küstengebiet vom 5. Jahrhundert v. Chr. bis zum 11. Jahrhundert n. Chr. 2: 339-66. Weinheim: Acta Humaniora.

-2006. Fürstengräber, Adelsgräber, Elitegräber: Methodisches zur Anthropologie der Prunkgräber, in C. von Carnap-Bornheim et al. (ed.) Herrschaft -Tod - Bestattung (Kongress Kiel 2003): 11-25. Bonn: Habelt.

Trotzig, G. 1991. Craftsmanship and function. A study of metal vessels found in Viking age tombs on the island of Gotland, Sweden. Stockholm: Statens Historiska Museum.

Zoll-Adamikowa, H. 1994. Die Einführung der Körperbestattung bei den Slawen an der Ostsee. Archäologisches Korrespondenzblatt 24: 81-93. 